\title{
A Case of Megaloblastic Anemia with Thrombocytopenia
}

\author{
Somayeh Moghadam ${ }^{*}$, Maryam Ghorbani2 \\ ${ }^{1}$ Alborz University of Medical Sciences, Alborz, Iran \\ ${ }^{2}$ Qom University of Medical Sciences, Qom, Iran \\ Email: "mgh_somi@yahoo.com
}

Received 5 April 2016; accepted 5 August 2016; published 8 August 2016

Copyright (C) 2016 by authors and Scientific Research Publishing Inc.

This work is licensed under the Creative Commons Attribution International License (CC BY).

http://creativecommons.org/licenses/by/4.0/

c) (i) Open Access

\begin{abstract}
Megaloblastic anemias are a group of hematologic disorders in which abnormal DNA synthesis causes blood and bone marrow disorders. This type of anemias occurs as a result of folic acid deficiency or impaired vitamin B12 absorption. The prevalence of this type of anemia is highly variable worldwide and megaloblastic anemia caused by lack of vitamin B12 (cyanocobalamin) is rare during pregnancy [1]. In this case report, we report follow-ups conducted for a pregnant 33-yearold woman, G2, P1, with a history of previous natural childbirth who attended Kamali Hospital due to labor pain associated with severe thrombocytopenia. Although this woman was injected 10 units of PLT and also vitamin B12 (cyanocobalamin), folic acid and corticosteroids in the course of treatment, her platelet level has not yet returned to normal levels after 6 months and she is still being treated.
\end{abstract}

\section{Keywords}

Megaloblastic Anemia, Folic Acid, Vitamin B12

\section{Introduction}

After anemia, thrombocytopenia is the most common pregnancy disorder among blood disorders and occurs in $10 \%$ of pregnancies [2]. Thrombocytopenia in pregnant women may be associated with maternal and neonatal complications [3]. Gestational thrombocytopenia is defined as platelet count less than 150,000 per microliter [4]. If the platelet count is between 100,000 to 150,000 per microliter, thrombocytopenia is mild and if it is less than 100,000 per microliter it is severe [5] [6]. Gestational thrombocytopenia has different reasons that are sometimes similar in terms of clinical symptoms and it may be difficult to determine the exact cause [7]. Gestational throm-

${ }^{*}$ Corresponding author. 
bocytopenia constitutes $74 \%$ of thrombocytopenias; $21 \%$ of them are due to hypertension and $4 \%$ are due to Idiopathic Thrombocytopenic Purpura (ITP) and in rare cases are due to gestational fatty liver, Disseminated Intravascular Coagulation (DIC), Thrombotic Thrombocytopenic Purpura (TTP) and antiphospholipid antibody syndrome [8].

Megaloblastic anemias are one of the causes of pancytopenias, a group of hematologic disorders in which blood and bone marrow disorders are caused by abnormal DNA synthesis [9]. This type of anemias occurs as a result of folic acid deficiency or impaired absorption of vitamin B12 (pernicious anemia) caused by severe Addison's anemia, complete or partial resection of stomach, resection of the ileum and the overgrowth of bacteria in the intestines and Crohn's disease [1]. Red blood cells may be macrocytic, normocytic or microcytic. Sometimes megaloblasts are seen in the blood smear; the sign of definitive diagnosis. The number of white blood cells can be decreased, increased or normal, but leukopenia is common. Thrombocytopenia is common, but has variable ranges. Blood bilirubin may increase. The definitive diagnosis is confirmed by bone marrow changes (with the simultaneous presence of megaloblasts and normoblasts). Almost all of megaloblastic anemias result from reduced absorption of vitamin B12 or folic acid deficiency.

Its prevalence throughout the world varies greatly and megaloblastic anemia caused by vitamin B12 deficiency (cyanocobalamin) is very rare during pregnancy.

This type of anemias causes curable anemias and pancytopenias; as a result its diagnosis and treatment are cost effective for patients and the society [10]. Typically, these diseases are diagnosed by low plasma folic acid levels (the first biochemical sign), hyper pigmentation of neutrophils (the first morphologic sign), significant increased Mean Corpuscular Volume (MCV), megaloblastic erythropoiesis in the bone marrow; although, there may be a slight anemia or vitamin B12 deficiency in pernicious anemia with neurological disturbances with normal MCV [11].

Fetus with severe thrombocytopenia is at the risk of acute bleeding, including intracranial hemorrhage. However, there is a less risk of having a baby with thrombocytopenia for women whose thrombocytopenia is diagnosed for the first time during pregnancy and who have no previous history [12] [13].

Matthews from the UK reported the prevalence of thrombocytopenia as 6.3\%, but maternal and neonatal complications were not reported [14]; whereas Zhang from China reported severe bleeding during childbirth in $11.7 \%$ of patients with thrombocytopenia [15]. The prevalence of thrombocytopenia was reported $8.8 \%$ by Modarresnejad in Kerman and 5.2\% in Babol [2].

Megaloblastic anemia is rarely seen in America and almost all cases are caused by folic acid deficiency and no precise figures have been provided so far about megaloblastic anemia in Iran.

\section{Case Report}

We followed up a pregnant 33-year-old woman with gestational age of 37 weeks and 3 days with a previous history of natural childbirth who was experiencing her second pregnancy and was hospitalized in Kamali Maternity Hospital due to labor pain with significant thrombocytopenia (PLT: 27000). Her blood tests are shown in Table 1.

Since thrombocytopenia in pregnant women may associated with maternal and neonatal complications, the first step of medical team (including hematologist-oncologist, internal physician, gynecologist and midwives responsible for the patient) when they visited the patient was a quick demand for reservation and preparation of

Table 1. Blood indexes of the case during hospitalization.

\begin{tabular}{|c|c|c|c|c|c|c|c|}
\hline Blood index & White blood cell & Red blood cell & Hemoglobin & MCV & Hematocrit & Platelets & Morphology \\
\hline $\begin{array}{l}\text { Patient status during } \\
\text { the visit }\end{array}$ & 9000 & $4.4 \times 10^{6}$ & 8.7 & 105.3 & 23 & 27000 & $\begin{array}{l}\text { Hypochromia } \\
\text { Macrocytosis } \\
\text { Endocytosis }\end{array}$ \\
\hline $\begin{array}{l}\text { After injection of } 10 \\
\text { units of PLT }\end{array}$ & 9200 & $4.2 \times 10^{6}$ & 8.4 & 103 & 24 & 41000 & $\begin{array}{l}\text { Slight hypochromia } \\
\text { Macrocytosis }\end{array}$ \\
\hline After childbirth & 9500 & $4 \times 10^{6}$ & 7.2 & 103 & 22.2 & 42000 & $\begin{array}{l}\text { Slight hypochromia } \\
\text { Macrocytosis }\end{array}$ \\
\hline $\begin{array}{l}\text { After blood } \\
\text { transfusion }\end{array}$ & 10000 & $4.1 \times 10^{6}$ & 8 & 103 & 24.2 & 80000 & $\begin{array}{l}\text { Slight hypochromia } \\
\text { Macrocytosis }\end{array}$ \\
\hline
\end{tabular}


10 units of PLT for infusion and ask consultation with hematology and internal physicians. Then we reviewed her medical records and found that she had no thrombocytopenia history during her previous pregnancy and used no supplements such as folic acid until the $28^{\text {th }}$ week of pregnancy. Early pregnancy tests showed 130,000 platelets in this pregnancy and 59,000 in week 28. After consultation with a hematologist, bone marrow biopsy and measurement of serum vitamin B12 were ordered. Once megaloblastic anemia in pregnancy was diagnosed in her, she underwent medication therapy including prednisolone tablets $(50 \mathrm{mg})$ twice a day for two months tapered to one tablet $(50 \mathrm{mg})$ per day, and half a tablet $(25 \mathrm{mg}$ ) for every other day in the last month, folic acid tablets (1 mg) daily with calcium, and vitamin B12 and B6 injections three times a week for 3 weeks during the last 21 days. In addition, visits with a hematologist and a gynecologist were continued every 2 weeks until the $28^{\text {th }}$ weeks, and then every week. During the series of tests carried out, platelet count did not change, and platelet and hemoglobin decreased more during the last days until spotting with labor pain occurred and she presented to Kamali Hospital.

After hematology consultation and due to a severe reduction in platelet count (below 100,000), 10 units of PLT were requested for injection, the preferred method of natural childbirth was advised and there was no need for blood transfusion until hemoglobin was reduced to less than eight. CBC, Diff, SGOT, SGPT, Billi (T, D), BS, BUN, and Cr tests were ordered, and the results were within normal ranges.

Internal consultant also requested dexamethasone $(80 \mathrm{mg})$ tds along with prednisolone as per order. Pantoprazole $(40 \mathrm{mg})$ bd with solution therapy $(2.3,1.3)$ bd was ordered until the time of childbirth. All measures required were performed carefully. After completion of PLT transfusion, CBC was checked again whose values are presented in Table 1. During the course of treatment, within 18 hours, the patient's amniotic sac suddenly ruptured, amniotic fluid was clear, the active childbirth process began, and the patient had a natural childbirth within eight hours with the help of a professional midwife and a gynecologist. Then, a baby girl was born with Apgar score of 9 - 10 and weight of 2800 g. Baby was transferred to neonatal department for further investigation and the mother was transferred to the intensive care unit one hour after childbirth.

Medication therapies after childbirth included tablets of folic acid (1 mg) per day, a dose of vitamin B12 injection and continuing pantoprazole for 24 hours and prednisolone by the patient, and another hematology consultation. After the patient visited the hematologist again, the injection of two units of packed red blood cells was ordered due to hemoglobin drop to 7.2 and then CBC was checked again within six hours. Then the hematologist asked for another visit three to four days after discharge. Measures were performed and after 24 hours of childbirth, the patient moved to postpartum department where she was monitored 48 hours and dexamethasone was reduced to one dose per day and her platelet count reached 80,000. Then the patient was advised to continue prednisone and visit the hematologist again within the next three days at discharge. We followed up the patient by telephone a week later and found that her prednisolone dose was being tapered by the hematologist and was supposed to be discontinued within two weeks. Medications administrated included ferrous sulfate and folic acid tablets, which are still being used. Platelet count during the first week and the first month reached 84,000 and 80,000, and hemoglobin reached 8.5 and 9, respectively. Now, after 6 months of her childbirth, her platelets count is 94,000 and hemoglobin is 9.7 , and her treatment will be continued by visiting the hematologist every two to three months until her platelets count reaches 100,000 .

\section{Discussion}

Megaloblastic anemia in pregnancy may occur in all pregnant women, either primigravida or multigravida. It often occurs in pregnant women under the age of 35 years and multifetal pregnant women and sometimes out of childbearing age. In pregnancy, this type of anemia is usually observed in the third trimester or postpartum period. General symptoms include general weakness, poor appetite and shortness of breath, accompanied by frequent gastrointestinal discomforts such as nausea and vomiting in more than $40 \%$ to $50 \%$ of women involved, diarrhea, heartburn and palpable splenomegaly (30\%). However, unlike non-pregnant women with this type of anemia who present to treatment centers with central nervous system symptoms [16], the central nervous system is not involved in pregnant women. Some people present to medical centers because of infection or blood poisoning and then are diagnosed with severe anemia through tests. However, the fetus and placenta extract folate from maternal circulation so efficiently that the fetus will not develop anemia even if the mother suffers severe anemia. It is important because the thrombocytopenia increases labor and postpartum hemorrhages.

In the case reported by Suarez (1951), only purpura and splenomegaly were observed and the patient was 
hospitalized with suspected aplastic anemia or allochemia and was diagnosed with megaloblastic anemia by bone marrow biopsy [10]. Sekhar reported three cases of pernicious anemia in non-pregnant women with normal MCV and different symptoms of dyspnea and hemoptysis, diabetes, gastritis, hepatitis $\mathrm{C}$, ataxia, and numbness in the extremities, syncope or skin rashes diagnosed with severe vitamin B12 deficiency, bone marrow and pancytopenia [17]. Others have also reported megaloblastic anemia associated with other diseases in non-pregnant women [18]; megaloblastic anemia is not studied in pregnant women perhaps because of its rare prevalence.

However in our case, the mother did not have any of the clinical symptoms mentioned and had not experienced them before and her decreased platelet count in the second trimester led to follow-up and diagnosis, and the methods used for diagnosis were similar.

Star, Pradat, Kelton et al. noted using prednisolone $(1 \mathrm{mg} / \mathrm{kg})$ for the treatment of thrombotic disorders in the first and second trimesters until it was effective and then tapering it to the lowest effective dose, and, if necessary, using corticosteroids with great caution, IVIg and finally splenectomy in unresponsive cases [19] [20]. The visit was advised as every 2 weeks after the $28^{\text {th }}$ weeks and each week after the $36^{\text {th }}$ weeks [21], which concurs with our study.

For childbirth method and termination of pregnancy, Klein from Germany reported nine out of sixteen cases of gestational thrombocytopenia to have natural childbirth and five to have cesarean delivery. Sekhar reported six out of eight cases of gestational thrombocytopenia to have natural childbirth and two to have cesarean delivery [17]. In our case, the childbirth was natural.

In recent years, few studies have been conducted on megaloblastic anemia in pregnancy, which can be attributed to its different prevalence rates in countries or a diet rich in vitamins and folic acid in pregnancy in most countries that prevents neural tube defects of the fetus and its rare incidence [22]. But due to sudden onset of anemias, which may lead to serious consequences during pregnancy and postpartum, it is clear how the second trimester screening tests to check anemia, even with normal blood parameters in the first trimester are effective in the prevention and treatment of anemia developed during pregnancy.

\section{Conclusion}

It is suggested that physicians ask about using supplements at each visit during pregnancy and remind clients the possible risks of not using those supplements, and in such cases, order necessary tests earlier than scheduled to prevent the deterioration of their condition.

\section{Acknowledgements}

The authors would like to express their sincere gratitude to the hospitals administrating team who helped in facilitating conduction of this study. Great appreciation as well is to the midwifery staff who accepted to participate in the current study.

\section{References}

[1] Kunningham, F.G., Hauth, J.C., Leveno, K.J., Gilstrap, L., et al. (2005) Hematologic Disorders, Williams Obstetrics. 20th Edition, Chapter 5, 1325-1326.

[2] Yazdani, Sh., et al. (2013) Prevalence of Trombocytopenia. Journal of Mazandaran University of Medical Sciences, 89 , 59-64. (In Persian)

[3] Stavrou, E. and McCrae, K.R. (2009) Immune Thrombocytopenia in Pregnancy. NIH Public Access, 23, $1299-1316$. http://dx.doi.org/10.1016/j.hoc.2009.08.005

[4] Provan, D., Stasi, R., Newland, A.C., et al. (2010) International Consensus Report on the Investigation and Management of Primary Immune Thrombocytopenia. Blood, 115, 168-186. http://dx.doi.org/10.1182/blood-2009-06-225565

[5] Duffy, T.P. (1995) Hematologic Aspects of Pregnancy. In: Burrow, G.N. and Ferris, T.F., Eds., Medical Complications during Pregnancy, 4th Edition, Saunders, Philadelphia, 72-79.

[6] Modarresnejad, V. and Motamedi, B. (2001) Study of the Prevalence of Thrombocytopenia and Factors Affecting It in Kerman. Asrar, 9, 4-10. (Persian)

[7] McCrae, K.R. (2003) Thrombocytopenia in Pregnancy, Differential Prognosis, Pathogenesis and Management. Blood Reviews, 17, 7-14. http://dx.doi.org/10.1016/S0268-960X(02)00056-5

[8] Kam, P.C., Thompson, S.A. and Liew, A.C. (2004) Thrombocytopenia in the Parturient. Anaesthesia, 59, $255-264$. 
http://dx.doi.org/10.1111/j.1365-2044.2004.03576.x

[9] Handin, R.I. (1995) Hematology and Oncology. 4th Edition, 72-79.

[10] Sifakis, S. and Pharmakides, G. (2000) Anemia in Pregnancy. Annals of the New York Academy of Sciences, 900, 125136. http://dx.doi.org/10.1111/j.1749-6632.2000.tb06223.x

[11] Tess Trueman, E.G., Sherma, L. and Boyd, A. (1959) Megaloblastic Anaemia of Pregnancy with Severe Thrombocytopenic Purpura-Case Report and Review of the Literature. Canadian Medical Association Journal, 81, 243-247.

[12] Kaplan, C. (2006) Foetal and Neonatal Alloimmune Thrombocytopaenia. Orphanet Journal of Rare Diseases, 1, 39. http://dx.doi.org/10.1186/1750-1172-1-39

[13] Yamada, H., Karo, E.H., Kishida, T., Negishi, H., Makinoda, S. and Fajimoto, S. (1998) Risk Factors for Neonatal Thrombocytopania in Pregnancy Complicated by Idiopathic Thrombocytopenic Purpura. Annals of Hematology, 76, 211-214. http://dx.doi.org/10.1007/s002770050391

[14] Matthews, J.H., Benjamin, S., Gill, D.S. and Smith, N.A. (1990) Pregnancy-Associated Thrombocytopenia: Definition, Incidence and Natural History. Acta Haematologica, 84, 24-29. http://dx.doi.org/10.1159/000205022

[15] Zhang, M.M. and Jiang, B. (1992) Clinical Analysis of 60 Cases of Pregnancy with Thrombocytopenia. Chinese Journal of Clinical Obstetrics and Gynecology, 27, 224-226, 250-251.

[16] Rannelli, L., Watterson, R., Pandya, R. and Leung, A.A. (2014) Vitamin B12 Deficiency with Combined Hematological and Neuropsychiatric Derangements: A Case Report. Journal of Medical Case Reports, 8, 277. http://dx.doi.org/10.1186/1752-1947-8-277

[17] Sekhar, J. and Stabler, S.P. (2007) Life-Threatening Megaloblastic Pancytopenia with Normal Mean Cell Volume. Case Series. European Journal of Internal Medicine, 18, 548-550. http://dx.doi.org/10.1016/j.ejim.2007.02.023

[18] Bappal, B., Nair, R., Shaikh, H., Al Khusaiby, S.M. and de Silva, V. (2001) Five Years Follow-Up of Diabetes Mellitus in Two Siblings with Thiamine Responsive Megaloblastic Anemia. Indian Pediatrics, 38, 1295-1298.

[19] Pradat, P., Robert-Gnansia, E., Di Tanna, G.L., et al. (2003) First Trimester Exposure to Corticosteroids and Oral Clefts. Birth Defects Research Part A: Clinical and Molecular Teratology, 67, 968. http://dx.doi.org/10.1002/bdra.10134

[20] Kelton, J.G. (2002) Idiopathic Thrombocytopenic Purpura Complicating Pregnancy. Blood Reviews, 16, 43. http://dx.doi.org/10.1054/blre.2001.0181

[21] Ajzenberg, N., Dreyfus, M., Kaplan, C., et al. (1998) Pregnancy-Associated Thrombocytopenia Revisited: Assessment and Follow-Up of 50 Cases. Blood, 92, 4573.

[22] Townsley, D.M. (2013) Hematologic Complications of Pregnancy. Seminars in Hematology, 50, $222-231$. http://dx.doi.org/10.1053/j.seminhematol.2013.06.004

\section{Submit or recommend next manuscript to SCIRP and we will provide best service for you:}

Accepting pre-submission inquiries through Email, Facebook, LinkedIn, Twitter, etc.

A wide selection of journals (inclusive of 9 subjects, more than 200 journals)

Providing 24-hour high-quality service

User-friendly online submission system

Fair and swift peer-review system

Efficient typesetting and proofreading procedure

Display of the result of downloads and visits, as well as the number of cited articles

Maximum dissemination of your research work

Submit your manuscript at: http://papersubmission.scirp.org/ 